УДК 930.2 (477) «18/19»

DOI: https://doi.org/10.33782/eminak2021.2(34).536

\title{
ТРУД МУЗЕОГРАФА: ПІДГОТОВКА МУЗЕЙНОГО ВИДАННЯ В УКРАЇНІ (КІНЕЦЬ ХІХ - ПЕРША ТРЕТИНА ХХ СТОЛІТТЯ)
}

\author{
Наталія Чергік \\ Національний заповідник «Хортиця» (Запоріжжя, Україна) \\ e-mail: cherhik.n@gmail.com \\ ORCID: https://orcid.org/0000-0003-4597-7184
}

У статті проаналізовані українські музейні видання кіния ХІХ - першої третини ХХст. з точки зору підготовки авторами музеографічних текстів. Приділено увагу об'ємам опрацювання музейних колекцій та особливостям роботи над укладанням каталогів, путівників, альбомів, описів, музейних звітів, музейних збірників. Представлена широта ерудищії осіб, долучених до публіцистично-поліграфічної діяльності українських музеїв зазначеного періоду.

Ключові слова: музеографія, музейне видання, каталог, альбом, путівник, звіт, збірник, автор, музеограф

В ювілейному збірнику, присвяченому 25-літтю Національного музею у Львові, Іларіон Свєнціцький відзначив, що підготовка музейного видання потребує багато часу, справжніх дослідників і коштів ${ }^{1}$. У даній статті звернемо увагу на труд автора музейного твору.

Можна назвати чимало біографічних студій, в яких робота над музейним виданням подана у контексті життєвих колізій і професійної активності науковців. Серед таких досліджень роботи С. Білоконя, в яких висвітлено музеографічну діяльність Федора Ернста² та Поліни Кульженко ${ }^{3}$. Надзвичайно широка письменницька нива музейної тематики Петра Руліна, представлена у роботі Л. Іващук ${ }^{4}$ Активна публікаційна сфера Євгенії Спаської розкрита у роботах Г.Скрипник ${ }^{5}$, О. Школьної6, Р. Маньковської7. Публіцистичній діяльності співробітників Музею українських діячів науки і мистецтва приділив увагу О. Бонь ${ }^{8}$. Діяльність колекти-

\footnotetext{
1 Двайцятьпять-ліття Національного музею у Львові. Збірник під редакцією директора музею I. Свєнціцького. / Наукова фундація Галицького митрополита Андрея Шептицького (1905-1930). Львів: «Діло», 1931. С. 14.

2 Білокінь С. В обороні української спадщини: Історик мистецтва Федір Ернст. Київ: Інститут історії України НАН України, 2006. 286 c. URL: https://www.s-bilokin.name/Personalia/Ernst.html

${ }^{3}$ Білокінь С. Поліна Кульженко: На зламі епохи. URL: https://www.sbilokin.name/Bio/Memoirs/Kulzhenko.html

${ }^{4}$ Іващук Л.А. Петро Іванович Рулін - перший директор Музею театрального, музичного та кіномистецтва України // Українська біографістика: Зб. наук. пр. Київ. 2010. Вип. 7. С. 180-191.

${ }^{5}$ Народознавчі та мистецтвознавчі праці Євгенії Спаської / Гол. ред. Г. Скрипник. НАН України, ІМФЕ ім. М. Рильського. Київ, 2015. С. 5-53.

6 Школьна 0. Непересічний дослідник волокитинського фарфору Ївга Спаська: до 125-річчя від дня народження // Мистецтво, історія, сучасність, теорія. 2015. Вип. 11. С. 311-315.

7 Маньковська Р.В. Музеї України у суспільно-історичних викликах XX - початку XXI століть. Львів: Простір-М, 2016. С. 133-140.

8 Бонь О.І. Діяльність Музею українських діячів науки і мистецтва в умовах наростання тиску тоталітарного режиму у кін. 1920-1930-х рр. // Література та культура Полісся. 2007. Вип. 39: Історія та культура Полісся й України в сучасному науковому сприйманні. С. 149-158.
} 
ву науковців Всеукраїнського Музейного містечка над формуванням серії випусків збірника «Український музей» і виходом у світ першого його тому досліджена

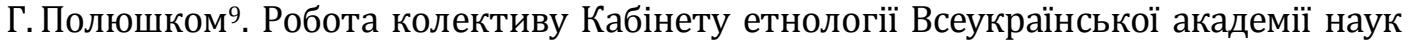
над серією «Матеріалів до монографії с. Старосілля» (збірник наукових праць співробітників Музею антропології та етнології імені Федора Вовка) представлена у праці М. Беха ${ }^{10}$. Робота над формуванням збірників Музею Бойківщини - «Літопис Бойківщини» висвітлена у дослідженні Р. Голика11.

Треба відзначити, що автори українських музейних творів кінця XIX - першої третини XX ст. не обійдені увагою сучасних науковців. Однак відомості про їх музеографічну діяльність розпорошені по дослідженнях різної спеціалізації. Сприймаючи музеографію за особливий пласт наукової та науково-популярної літератури, робота над якою потребувала специфічної діяльності автора, вважаємо огляд діяльності музеографа достойним окремої уваги. Такий підхід сприятиме якісно новому розумінню соціокультурної ролі музеїв. Дослідження розвитку музейної справи в Україні через аспект друкованої презентації суспільству діяльності музею та його колекцій, дозволить більш глибоко розкрити зв'язок музеїв із наукою та мистецтвом.

Виходячи із вище сказаного, об'єктом даного дослідження є українські музейні видання кінця XIX - першої третини XX ст., а саме: каталоги, альбоми, описи, путівники, звіти, збірники, монопублікації. Предмет дослідження - грані музейної діяльності, пов'язані із створенням музейного друкованого продукту. Задача даної роботи - представити відомих науковців і музейників зазначеного періоду як музеографів, не торкаючись біографічних аспектів їх життя. Аналіз проведено блоками:1) робота над описом колекції; 2) укладання звіту музею; 3) підготовка музейного збірника.

У залежності від типу музейного видання, його підготовка включала різні види наукової діяльності. Випуск каталогу, альбому, опису, путівника потребував попереднього опрацювання колекції, ï систематизації й атрибуції, опрацювання досвіду вітчизняних і зарубіжних колег. Про масштаби підготовчої фази промовисто свідчать тисячі описаних предметів, чисельні бібліографічні посилання, фахово складені історичні довідки. Наведемо кілька прикладів.

Без перебільшення фундаментальну роботу провів Володимир Антонович. Підготовлений ним опис монет і медалей нумізматичного музею університету св. Володимира, виданий трьома випусками, сукупно містить близько 9000 предметів мюнц-колекції. В.Б. Антонович атрибутував їх за принципами Моннета (Mionnet), Ернеста Бабелона (Ernest Babelon), Генрі Когена (Henri Cohen) та інших фахівців. Автор оснастив «Описи» потужним довідковим апаратом ${ }^{12}$.

\footnotetext{
9 Полюшко Г. До історії видання збірника «Український музей», 1927 // Київська старовина. 2008. Вип. 2. С. 84-97.

10 Бех М.В. Монографічне дослідження села в етнології: історія та подальші перспективи // Збірник наукових праць Харк. нац. пед. ун-т імені Г.С. Сковороди. Серія «Історія та географія». Харків. 2012. Вип. 45. С. 35-40.

11 Голик Р. Книги, ідеї та стереотипи галицької провінції XX ст.: «Літопис Бойківщини» у міжвоєнному Самборі // Записки Львівської національної наукової бібліотеки України імені В. Стефаника. 2009. № 1. С. 223-248.

12 Описание монет и медалей, хранящихся в нумизматическом музее Университета св. Владимира. Монеты древнего мира. Составил проф. В. Антонович. Киев: Типография Императорского Университета св. Владимира В.І. Завадского, 1896. Выпуск I. 283 с.; Описание монет и
} 
В останньому випуску «Альбому старожитностей Церковно-археологічного музею при Імператорській Київській духовній академії» професор Микола Петров неодноразово посилається на свій же труд «Рукописний додатковий каталог». Очевидно, рукопис не призначався для опублікування, а був результатом поточної музейної роботи з систематизації й атрибуції колекції. Він містить більше 3000 номерів. Якщо говорити про останній випуск серії «Альбомів», то за невиправдано скромним визначенням самого автора, він намагався предметами музейної колекції подати «більш або менш посильне відображення історії культури південнозахідної та західної Росії, а також її Церкви, у зв'язку з її загальнолюдською та загальнохристиянською культурою»13. Автору вдалося занурити читача у світ християнської археології, археологічної науки та практики. Робота охоплює період від найдавніших часів («присінок християнства» за M.I. Петровим) до кінця XVIII ст.14

Певною мірою новаторською можна назвати роботу Сергія Кулжинського над підготовкою опису колекції писанок приватного зібрання К.М.Скаржинської. Не вважаючи себе за «спеціаліста-етнографа», він склав бібліографію писанкарства, виклав історію виникнення та розвитку традиції фарбування і розмальовування яєць, запропонував класифікацію писанок, подав «Програму щодо збирання народних писанок», поділився досвідом їх зберігання та експонування, систематизував колекцію К.М. Скаржинської. В «Описі» представлено більше 2000 екземплярів 15 .

Часто об’єм колекції або специфіка збірки, що планувалася для опублікування, була не під силу одній особі та потребувала колективних зусиль. Наприклад, до укладання каталогу виставки XI-го Археологічного з'їзду було задіяно восьмеро фахівців. Більшу частину роботи виконала Катерина Мельник, підготувавши описи археологічних старожитностей (8567 позицій). Її колегами в роботі над виданням були: Ф.І. Тітов, М.І. Істомін, Ю.А. Кулаковський, В.З. Завитневич, В.І. Щербина, В.А. Корт, I.M. Каманін. Сукупно у каталозі представлено більше 10000 експонатів ${ }^{16}$.

К.М. Мельник описала близько 5000 предметів приватної збірки О.М. Поля. У роботі їй допомагали: В.Б. Антонович - він проаналізував колекцію монет і медалей (2 060 одиниць), а гірничий інженер Гонсеровський визначив гірські породи в предметах кам'яного віку17.

Володимир Тарновський для роботи над першим випуском каталогу своєї збірки запросив Миколу Біляшівського - він опрацьовував предмети доісторичної до-

медалей, хранящихся в нумизматическом музее Университета св. Владимира. Монеты Римской республики. Составил проф. В. Антонович. Киев: Типография Императорского Университета св. Владимира Н.Т. Корчак-Новицкого, 1900. Выпуск II. 118 с.; Описание монет и медалей, хранящихся в нумизматическом музее Университета Св. Владимира. Монеты Римской империи (От Юлия Цезаря до Коммода). Составил проф. В. Антонович. Киев: Типография Императорского Университета св. Владимира Акц. О-ва печ. и изд. дела Н.Т. Корчак-Новицкого, 1906. Выпуск III. 365 с. 13 Альбом достопримечательностей Церковно-археологического музея при Императорской Киевской духовной академии. Киев: фото-лито-топография «С.В. Кульженко», 1915. Выпуск IV-V. C. 2. 14 Ibid. 62 c.

15 Описание коллекции народных писанок. Вып. 1. С альбомом из 33 хромолитографированных и 12 чёрных таблиц (всего 2219 рисунков). Составил С.К. Кулжинский, Действительный член Императорского Русского Географического Общества. / Лубенский Музей Е.Н. Скаржинской. Этнографический отдел. Москва: Поставщик Высочайшего Двора Т-во Скоропечатни А.А.Левенсон, 1899. 176 с.

16 Каталог выставки ХІ-го Археологического съезда в Киеве (в здании Университета св. Владимира). Киев: Типо-литография Товарищества И.И. Кушнерев и Ко, 1899. 288 с.

17 Каталог коллекции древностей А.Н. Поль, в Екатеринославе. Составила К. Мельник. Киев: типография С.В. Кульженко, 1893. Выпуск I. С. V. 
би та великокнязівського періоду. Решту колекції описав сам власник. Сукупно каталог містить близько 3000 позицій 18.

Текстові матеріали до каталогу виставки, присвяченої Г.І.Нарбуту, готували Федір Ернст та Ярослав Стешенко. Вони старанно описали близько 1000 творів Г.І. Нарбута та матеріали про нього. Ф.Л. Ернст виклав детальну за фактами, насичену ексклюзивними відомостями й одночасно душевну за стилем біографію свого покійного друга ${ }^{19}$.

Матеріали каталогу виставки, присвяченої Миколі Лисенку, а це 830 предметів, підготували: Людмила Старицька-Черняхівська - склала повний бібліографічний покажчик творів М.В. Лисенка, та Євгенія Рудинська - автор передмови і решти розділів каталогу 20.

Зауважимо, що вибір стилю написання (науковий або науково-популярний), ступінь деталізації описів, міра оснащення публікації додатковим матеріалом і довідковим апаратом - залежали від багатьох факторів: об'єму колекції, авторського досвіду музейної атрибуції, мети видання та його орієнтації на певну читацьку аудиторію. У будь-якому варіанті не викликає сумніву колосальна підготовча робота, проведена авторами музейних каталогів, описів, путівників, альбомів.

Підготовка «Звіту» вимагала аналізу роботи музею в різних сферах його діяльності за певний період. Авторами текстів виступали дирекція музею, член(и) Комітету музею, спеціально запрошені спеціалісти.

Звіт являє собою специфічний жанр, якому притаманне узагальнення фактів, підведення статистичних і фінансових розрахунків. Автори «Звітів» зазвичай торкались таких тем: штатні одиниці - їх кількість, галузь діяльності, оплата праці; кількість набутих предметів до кожного відділу музею, іноді з вказівкою їх оціночної вартості (якщо це дар); кількість відвідувачів - їх представлено за категоріями та з розбивкою по днях тижня, місяцях або роках; фінансові витрати - на утримання будівлі та персоналу, на проведення експедиційних, консерваційних, реставраційних робіт; прибутки - з оренди приміщень, продажу непотрібного майна чи обладнання, вхідних квитків, видань та іншого роду музейної продукції або послуг. У звітах відзначені досягнення і недоліки комплектування збірки, стан експозиційної, виставкової та наукової роботи.

Треба зазначити, що зведена у таблиці суха статистика супроводжується достатньо емоційно складеними текстами, через які проступає нелегка робота музейників. Так, у звіті Природничо-історичного музею Таврійського губернського земства йдеться про труднощі комплектування колекції, спричинені несприятливими погодними умовам: «У зв'язку із швидким цвітінням плодових дерев також швидко пройшов і літ грушевого пильщика <..>. Коли зберігач музею приїхав до Алушти, літ пильщика уже припинився і вдалося зібрати лише личинок у зав'язях груш і зразки пошкоджень»21. У цьому ж «Звіті» повідомлено про неукомплектований

\footnotetext{
18 Каталог украинских древностей коллекции В.В. Тарновского, с приложением 16-ти таблиц фототипных снимков. Киев: типография К.Н. Миловскаго, 1898. 86 с.

19 Георгій Нарбут: посмертна виставка творів / Всеукраїнський історичний музей ім. Т. Шевченка. Київ: Державне видавництво України, Трест «Київ-Друк», 1926. 168 с.

${ }^{20}$ Каталог виставки, присвяченої Миколі Лисенкові: з нагоди 85-ліття з дня його народження і 15-ліття з дня смерті: 1842-1912-1927. / Музей українських діячів науки та мистецтва. Українська Академія Наук. Київ: Держтрест «Київ-Друк», 1-ша фото-літо-друкарня, 1927. 40 с.

21 Отчет по естественно-историческому музею Таврического Губернского земства за 1907 год. Год XVIII-ой. Симферополь: Типография Таврического Губернского земства, 1908. С. 5.
} 
штат співробітників і неадекватну такій кількості завантаженість: всього чотири особи - завідувач музею, зберігач музею, препаратор, діловод-бібліотекар. Ось тільки один приклад: «Вигодовування хробаків і догляд за ними, відбір різноманітних стадій гусені та їх видування (для колекції їх довелося видути декілька тисяч), препарування лялечок і коконів, розправлення метеликів та інших комах для 500 шкільних колекцій поглинули увесь весняний період часу» 22 . Зауважено, що цією роботою займався один співробітник - препаратор музею, який після звільнення зберігача музею виконував ще і його функції 23.

Іншого роду проблеми описані у першому «Звіті» Театрального музею - ігнорування новоутвореної установи колегами по цеху або нехтування ії інтересів на вищих щаблях. Тож, основу «Звіту» складають розповіді, місцями з елементами драми, в яких йдеться про добування предметів театральної колекції різноманітними шляхами: уведенням «примусового музейного податку» для членів театральної трупи «Березіль»; «вилазок до старших акторів»; затягування до музею «якогось принципового ворога його, що мав цінні речі для музею» щоб зворушити його серце; ведення спрямованої «боротьби» за музейні шедеври - «Сокиренський вертеп», «Славутинську вертепну скриньку», матеріали Одеської Держдрами та низка інших експонатів ${ }^{24}$.

Крім озвучення основних досягнень, проблем і перспектив, автори «Звітів» віддали належне «жертводателям», назвавши їх поіменно, з вказівкою роду пожертв, кількості предметів або грошової суми. При чому, не мало значення наскільки вагомою була допомога музеєві: указані всі особи - і ті, хто приніс зуб невідомої тварини, і ті, хто передав рідкісну історичну або мистецьку річ. Так, у «Звіті» Городецького музею Волинської губернії барона Ф.Р. Штейнгеля названо 23 особи, які наповнили своїми дарами різні відділи музею у перший рік його роботи. Серед них: баронеса Н.К.Врангель, граф Б.Г.Толстой, художник Є.М. Маковський, історик С.М. Грушевський та інші25. У звіті Природничо-історичного музею Таврійського губернського земства за 1907 р. названо 36 осіб, залучених до процесу поповнення й оформлення вельми специфічної колекції. Серед них Ф.Е.Фальц-Фейн, члени Зоологічної академії наук та інші особи ${ }^{26}$. Близько 90 осіб виступили дарувальниками Київського художньо-промислового музею імені Імператора Миколи Олександровича у 1910 р. Серед них: подружжя Б.І. та В.М. Ханенків, барон В.Г. Гінцбург і К.Л. Гінцбург, Н.І. Врубель (дружина М.О. Врубеля), художники Г.К. Лукомський та А.Г. Сластіон, власник типографії В.С. Кульженко та багато інших ${ }^{27}$. В останній рік роботи Волинського центрального музею як складової Товариства дослідників Волині (1913) пожертви музею склали щонайменш 68 осіб - це переважно вчителі

\footnotetext{
22 Ibid. C. 5.

23 Ibid. C. $5,12$.

24 Звіт 1926-1929. Театральний музей / Всеукраїнська Академія Наук. Київ: Київ-Друк, Друга друкарня, 1930. С.2-3, 8, 12, 17.

25 Отчет Городецкого музея Волынской губернии барона Ф.Р. Штейнгель за первый год с 25 ноября 1896 г. по 25 ноября 1897 г. Составил Н. Беляшевский. Варшава: Типография Ф. Чернака, 1898. C. $1-55$.

${ }^{26}$ Отчет по естественно-историческому музею Таврического Губернского земства за 1907 год... C. 16-19.

27 Отчет Киевского художественно-промышленного и научного музея имени Государя Императора Николая Александровича за 1910 год. Киев: Типография 1-й Киевской Артели Печатного Дела, 1911. C. 9-14.
} 
шкіл і гімназій, а також їхні вихованці (усі вони названі поіменно) ${ }^{28}$. Більше 80 осіб взяли участь у створенні колекції Театрального музею за перші п'ять років його діяльності - переважно діячі театру, серед них: усі «Березільці», а також актори старої плеяди М.К. Заньковецька, Л.П. Ліницька, С.Ф. Паньковський, М.М. Старицька й ін. ${ }^{29}$

В цілому, підготовка «Звіту» для публікації вимагала від автора уміння створити олюднене, панорамне зображення роботи музею.

Основу збірника або моновидання складали результати наукових досліджень 3 певної теми одним або кількома авторами. Тематика матеріалу, що готувався для публікації, залежала від задач конкретного випуску. Якщо узагальнено окреслити тематичний діапазон, то в цих виданнях публікували результати археологічних, етнографічних, мистецтвознавчих, біографічних досліджень. Чільне місце відведено історії певного краю, музею, історії мистецтва, предметам музейної колекції, егоджерелам.

Варто відзначити, що випуски музейних збірників набувають обертів з 1920-х років. Хто ж був долучений до такого роду музеографічної справи в 20-30-х роках ХХ століття?

До формування перших випусків «Херсонеського збірника» директором музею Костянтином Гриневичем були запрошені Григорій Бєлов і Любов Кудь-Бєлова. Матеріали цього збірника стосувалися перебігу археологічних досліджень Херсонесу Таврійського. Значна увага приділялась виявленим під час розкопок артефактів. На сторінках «Херсонеського збірника» К.Е. Гриневич звів воєдино результати попередніх і нових археологічних сезонів; Г.Д. Бєлов ознайомив з поточним станом досліджень; Л.М. Кудь-Бєлова увела до обігу та зробили доступним для вченої спільноти величезний нумізматичний матеріал Херсонесу30. Ясна річ, що писемній роботі передувала не менш часо- та енерговитратна експедиційна та камеральна фази.

Музей діячів науки та мистецтва України залучив до роботи над своїм «Збірником» знаних етнографів, музикознавців, фольклористів: Климента Квітку, Дмитра Ревуцького, Олексія Новицького, Євгенію Рудинську. Тематика першого випуску стосувалась персони Миколи Лисенка. Авторам вдалося представити М.В. Лисенка на фоні епохи, у колі однодумців, колег, родичів 31.

«Річник» Українського Театрального музею об’єднав навколо першого випуску теоретиків і діячів сценічного мистецтва. Василь Василько-Міляєв, Петро Рулін,

\footnotetext{
28 Отчет о деятельности Общества исследователей Волыни и Волынского центрального музея. За 1913 год. Житомир: Электрическая типография насл. М. Дененмана, 1915. С. XXXVII-XLV.

29 Звіт 1926-1929. Театральний музей... 23 с.

30 Гриневич К.Э. Стены Херсонеса Таврического. Подстенный склеп № 1012 и Ворота Херсонеса, открытые в 1899 году. / Издание Херсонесского музея. Севастополь: 2-я Гостипография «Крымполитграфтреста», 1926. Вып. I. 71 с.; Херсонесский сборник. Материалы по археологии Херсонеса Таврического под общей редакцией директора Херсонесского музея К.Э. Гриневича. / Издание Хероснесского музея. Севастополь: 2-я Гостипография «Крымполитграфтреста», 1927. Вып. II. 296 с.; Херсонесский сборник под редакцией К.Є. Гриневича, действительного члена научноисследовательского института археологии и искусствознания РАНИОН. / Издание Государственного Херсонесского музея. Севастополь: 2-я Гостипография «Крымполитграфтреста», 1930. Вып. III. 248 c.

31 Збірник Музею діячів науки та мистецтва України. Присвячений Миколі Лисенкові. Всеукраїнська Академія Наук. Збірник історично-філологічного відділу № 94. Київ: Трест «Київ-Друк», Школа ФЗУ ім. Балабанова, 1930. Том 1.178 с.
} 
Михайло Возняк, Володимир Рєзанов, Олександр Кисіль - запропонували дослідження історії розвитку українського театру. Спогади про театральну діяльність українських труп для збірника написали актори: В.Потапенко, Ф. Левицький, С. Паньківський, В. Петровська-Смирнова, В. Яременко 32 .

Редакційна колегія збірника «Український музей» для першого випуску запросила 36 авторів, роботи яких продемонстрували концепцію видання, показали його географічний і тематичний діапазон. Репертуар збірника вийшов доволі різноманітним. Тут представлені: роботи мемуарного характеру (автор К. Мощенко), виклад творчої біографії (Ф.Ернст), робота теоретико-музеологічного змісту (В. Дубовський), огляди колекцій або аналіз окремих музейних предметів

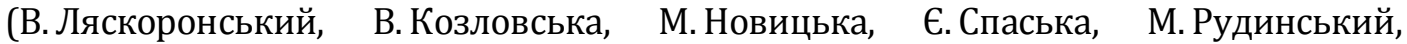
Д. Щербаківський, Л. Лінко), повідомлення про досвід роботи київських і периферійних музеїв (П.Курінний, С.Дложевський, А.Дахнович, Є.Сташевський, Ю. Александрович, М. Щепотьєва, Н. Онацький, В. Бабенко, М. Сібільов, І. Коваленко, С. Дродов, М. Вайнштейн, Ю. Виноградський, С. Гапеєв, В. Омельченко, І. Гріненко, О. Кононенко, М. Константинов, П. Козар, В. Коренєв, Д. Карабанович, Р. Данковська й інші) ${ }^{33}$. Усі автори - професійні музейники. В цілому збірник вийшов доволі маніфестаційним - таким, що вглиб і вшир продемонстрував стан музейної справи в Україні у 1920-х роках.

Серію книг видав Музей антропології та етнології ім. Хведора Вовка, утворений Етнографічною комісією ВУАН. Публікаціям передувало вивчення побуту мешканців села Старосілля новаторським методом - стаціонарними етнографічними дослідженнями із «вживлянням» науковця у повсякденне середовище селян. Результат роботи втілився у створенні експозиції та друкованої продукції (путівник по музею, збірники, монопублікації). Їх авторам - Надії Загладі, Лідії Шульгіній, Юрію Павловичу, Євгенії Спаській - вдалося різнобічно охарактеризувати матеріальний і духовний світ «старосільців», продемонструвати культурні та господарчі трансформації на селі ${ }^{34}$.

Музей «Бойківщина» у другій половині 1930-х років випускав «Літопис Бойківщини» - краєзнавчий збірник з широким тематичним діапазоном. Відкривають журнал статті Володимира Гуркевича - організатора та голови (1928-1932) товариства, співзасновника музею, ініціатора створення журналу. Треба відзначити, що залучені до публікаційної роботи «бойківського» музею персони - люди широкої ерудиції, освіта й основна діяльність яких часто не мала відношення до історичної науки або музейної справи. Якщо певною мірою узагальнити пріоритетні напрямки їх досліджень, то можна сказати, що дописувачами збірника були: історіографи (Мирон Кордуба), археологи (Маркіян Смішко, Ярослав Пастернак), етнографи (Іван Максимчук, Ян Фальковські), мовознавці (Юрій Кміт, Ярослав Рудницький), правники (Іван Максимчук), педагоги (Іван Филипчак, Антін Княжинський), свя-

\footnotetext{
32 Річник Українського театрального музею: за редакцією П. Руліна. / Всеукраїнська Академія Наук. Київ Держтрест «Київ-Друк», 2-а друкарня, 1929. 236 с.

33 Український музей / Управління науковими установами УСРР. Київ: Держтрест «Київ-Друк», 1ша фото-літо-друкарня, 1927. Вип. 1. 309 с.

34 Матеріяли до монографії с. Старосілля. Матеріяли до етнології. / Всеукраїнська Академія Наук. Музей антропології та етнології ім. Хведора Вовка. Київ: УПО Київська школа ФЗУ, 1931. Вип. III. 190 с.; Бех М.В. Монографічне дослідження села в етнології: історія та подальші перспективи // Збірник наукових праць Харк. нац. пед. ун-т імені Г.С. Сковороди. Серія «Історія та географія». Харків. 2012. Вип. 45. С. 35-40.
} 
щеники (Роман Лукань). Кожен із них поклав свою лепту у справу оприлюднення матеріальної та нематеріальної культурної спадщини регіону 35 .

Ілюстрацією авторського контингенту «Збірника» Національного музею у Львові можна назвати спеціальний його випуск, присвячений 25-літтю музею, який зібрав під однією обгорткою усіх осіб, залучених до розбудови та роботи музею. Серед авторів, що склали спомини про свою роботу в музеї, відомі імена: Андрій Шептицький (засновник музею), Петро Холодний (член комітету музею), Іларіон Свєнціцький (директор музею), Амвросій Андрохович, Вадим Щербаківський, Микола Чубатий, Іван Чорняк, Михайло Драган, Ірина Гургула, Богдан Кравців, Ярослава Музика, Євген-Юрій Пеленський та інші ${ }^{36}$.

Не обмежуючись участю у створенні збірників, більшість названих авторів видавали персонально написані праці або перевидавали окремою брошурою роботу, раніше опубліковану у збірнику. Не маючи можливості представити у даному екскурсі усіх учасників музейної публіцистики, зауважимо на тому, що своїм долученням до діяльності музеїв у справі формування музейного збірника або окремо випущеної авторської праці усі вони значно розширили та збагатили когорту українських музеографів кінця XIX - першої третини XX ст.

Підсумовуючи, відзначимо наступне. Зародження концепції музейного видання будь-якого типу йоб’єму - творчий процес. Проте, його письмова вербалізація вимагала від автора наукового підходу, обгрунтованості суджень, об’єктивності в інтерпретації фактів і предметів музейної колекції. Це кропітка робота «старателя» та «ювеліра» в одній особі, що по крупинці збирає необхідний матеріал з величезного масиву культурної скарбниці й утворює із здобутого цілісний інтелектуальний продукт.

Тематичний асортимент українських музеографічних творів кінця XIX - першої третини XX ст. демонструє неабиякий азарт і завзяття у цьому руслі людей різного фаху, не завжди пов'язаних з роботою безпосередньо в музеї. Протягом зазначеного періоду спостерігаємо сталий інтерес авторів до археології (особливо античного матеріалу та нумізматики), етнографічного матеріалу, релігійних мотивів. У публікаціях ХХ ст. відображена тенденція вивчати матеріальні прояви традиційної культури через аспект повсякдення; «колекціонувати» не тільки матеріальний, а й нематеріальний аспект життєдіяльності. У 1920-х рр. з'являються нові музеографічні теми - український театр, українська музика, український музей. Актуальними в цей час стають роботи методологічного характеру з археології, етнографії, музейної справи.

Треба сказати, що творче, наукове, громадсько-політичне життя авторів музейних публікацій склалося не однаково. Одних спіткали репресії, арешти, хвороби,

35 Літопис Бойківщини. Записки присвячені дослідам історії, культури й побуту бойківського племені. Видає Музей Т-ва «Бойківщина» в Самборі. Самбір: з друкарні Й. Мецгера, 1939. Рік IX. Частина 11. 117 с.; Літопис Бойківщини. Записки присвячені дослідам історії, культури й побуту бойківського племені. Видає Музей товариства «Бойківщина» в Самборі. Самбір: з друкарні Йосипа Мецгера, 1936. Рік VI. Частина 7. 77 с.; Літопис Бойківщини. Записки присвячені дослідам історії, культури й побуту бойківського племені. Видає Музей товариства «Бойківщина» в Самборі. Самбір: з друкарні Йосипа Мецгера, 1936. Рік VI. Частина 8. 85 с.; Літопис Бойківщини. Записки присвячені дослідам історії, культури й побуту бойківського племені. Самбір: Друкарня Йосифа Мецгера, 1937. Рік VII. Частина 9. 93 с.

36 Двайцятьпять-ліття Національного музею у Львові. Збірник під редакцією директора музею I. Свєнціцького. / Наукова фундація Галицького митрополита Андрея Шептицького (1905-1930). Львів: «Діло», 1931. 123 с. 
смерть, еміграція. Інших чекала краща доля та довге життя. Відповідно, музеографічний доробок одних був «репресований» і «реабілітований» лише з роками. Роботи інших ніколи не виходили з наукового ужитку наступників. Вивчення особливостей функціонування музейних творів у реаліях часу (зняття з друку, заборона на читання, широке розповсюдження) - перспективна задача дослідження стану української музеографії кінця XIX - першої третини XXI ст.

\section{REFERENCES}

Antonovich, V. (Comp.). (1896). Opisanie monet i medalei khraniashchikhsia v numizmaticheskom muzee Universiteta Sv. Vladimira. Monety drevnego mira [Description of coins and medals stored in the numismatic museum of the University of St. Vladimir. Coins of the Ancient World]. Vol. I. Kiev [in Russian].

Antonovich, V. (Comp.). (1900). Opisanie monet i medalei khraniashchikhsia v numizmaticheskom muzee Universiteta Sv. Vladimira. Monety Rimskoi respubliki [Description of coins and medals stored in the numismatic museum of the University of St. Vladimir. Coins of the Roman Republic]. Vol. II. Kiev [in Russian].

Antonovich, V. (Comp.). (1906). Opisanie monet i medalei khraniashchikhsia v numizmaticheskom muzee Universiteta Sv. Vladimira. Monety Rimskoi imperii (Ot Yuliia Tsezaria do Kommoda) [Description of coins and medals stored in the Numismatic Museum of the University of St. Vladimir. Coins of the Roman Empire (From Julius Caesar to Commodus)]. Vol. III. Kiev [in Russian].

Bekh, M. (2012). Monohrafichne doslidzhennia sela v etnolohii: istoriia ta podalshi perspektyvy [Monographic study of the village in ethnology: history and future perspectives]. Zbirnyk naukovykh prats Kharkivskoho natsionalnoho pedahohichnoho universytetu imeni H.S. Skovorody. Seriia «Istoriia ta heohrafiia», 45, 35-40 [in Ukrainian].

Bilokin, S. (2006). V oboroni ukrainskoi spadshchyny: Istoryk mystetstva Fedir Ernst [In defense of Ukrainian heritage: Art historian Fedor Ernst]. Kyiv [in Ukrainian].

Bilokin, S. Polina Kulzhenko: Na zlami epokhy [Polina Kulzhenko: At the turn of the era]. Retrieved from https://www.s-bilokin.name/Bio/Memoirs/Kulzhenko.html [in Ukrainian].

Beliashevskii, N. (Comp.). (1898). Otchet Gorodetskogo muzeia Volynskoi gubernii barona F.R.Shteingel za pervyi god s 25 noiabria $1896 \mathrm{~g}$. po 25 noiabria $1897 \mathrm{~g}$. [Report of the Gorodets Museum of the Volyn province of Baron F.R. Steingel for the first year from November 25, 1896 to November 25, 1897]. Varshava: Tipografiia F. Chernaka [in Russian].

Bon, 0. (2007). Diialnist Muzeiu ukrainskykh diiachiv nauky i mystetstva v umovakh narostannia tysku totalitarnoho rezhymu u kintsi 1920 - 1930-kh rr. [The activity of the Museum of Ukrainian Figures of Science and Art in the conditions of increasing pressure of the totalitarian regime in the late $1920 \mathrm{~s}$ - 1930s]. Literatura ta kultura Polissia, 39, 149-158 [in Ukrainian].

Holyk, R. (2009). Knyhy, idei ta stereotypy halytskoi provintsii XX st.: «Litopys Boikivshchyny» u mizhvoennomu Sambori [Books, ideas and stereotypes of the Galician province of the XX century: «Chronicle of Boikivshchyna» in interwar Sambor]. Zapysky Lvivskoi natsionalnoi naukovoi biblioteky Ukrainy imeni V. Stefanyka, 1, 223-248 [in Ukrainian].

Grinevich, K.E. (Ed.). (1926). Steny Khersonesa Tavricheskogo. Podstennyi sklep № 1012 i Vorota Khersonesa, otkrytye $v 1899$ godu [Walls of Tauric Chersonesos. Under-wall crypt No. 1012 and the Chersonese Gate, opened in 1899]. Vol. I. Sevastopol [in Russian].

Grinevich, K.E. (Ed.). (1927). Khersonesskii sbornik. Materialy po arkheologii Khersonesa Tavricheskogo [Chersonesos collection. Materials on the archeology of Tauric Chersonesos]. Vol. II. Sevastopol [in Russian].

Grinevich, K.E. (Ed.). (1930). Khersonesskii sbornik [Chersonesos collection]. Vol. III. Sevastopol [in Russian].

Ivashchuk, L. (2010). Petro Ivanovych Rulin - pershyi dyrektor Muzeiu teatralnoho, muzychnoho ta kinomystetstva Ukrainy [Petro Ivanovych Rulin is the first director of the Museum of Theatre, Music and Cinematography of Ukraine]. Ukrainska biohrafistyka, 7, 180-191 [in Ukrainian].

Kulzhinskii, S.K. (Comp.) (1899). Opisanie kollektsii narodnykh pisanok [Description of the collection of folk Easter eggs]. Vol. 1. Moskva [in Russian].

Melnik, K. (Comp.) (1893). Katalog kollektsii drevnostei A.N. Pol v Ekaterinoslave [Catalog of the collection of antiquities by A.N. Paul in Yekaterinoslav]. Vol. I. Kiev [in Russian].

Mankovska, R. (2016). Muzei Ukrainy u suspilno-istorychnykh vyklykakh XX - pochatku XXI stolit [Muse- 
ums of Ukraine in the socio-historical challenges of the XX - early XXI centuries]. Lviv: Prostir-M [in Ukrainian].

Poliushko, H. (2008). Do istorii vydannia zbirnyka «Ukrainskyi muzei», 1927 [To the history of the publication of the corpus «Ukrainian Museum», 1927]. Kyivska starovyna, 2, 84-97 [in Ukrainian].

Rulin, P. (Ed.) (1929). Richnyk Ukrainskoho teatralnoho muzeiu [Yearbook of the Ukrainian Theater Museum]. Kyiv [in Ukrainian].

Skrypnyk, H. (2015). Narodoznavchi ta mystetstvoznavchi pratsi Yevhenii Spaskoi [Ethnographic and art studies works of Eugenia Spaska]. Kyiv: Natsionalna Akademiya Nauk Ukrainy. Instytut mystetstvoznavstva. Folklorystyky ta etnolohii im. M. Rylskoho [in Ukrainian].

Shkolna, 0. (2015). Neperesichnyi doslidnyk volokytynskoho farforu Yivha Spaska: do 125-richchia vid dnia narodzhennia [An outstanding researcher of Volokytyn porcelain Yivha Spaska: to the $125^{\text {th }}$ anniversary of his birth]. Mystetstvo, istoriia, suchasnist, teoriia, 11, 311-315 [in Ukrainian].

Svientsitskyi, I. (Ed.) (1931). Dvadtsiatypiatylittia Natsionalnoho muzeiu u Lvovi. Zbirnyk [Twenty-fifth Anniversary of the National Museum in Lviv. Collection]. Lviv [in Ukrainian].

\section{Nataliia Cherhik}

(National reserve «Khortytsia», Zaporizhzhia, Ukraine)

e-mail: cherhik.n@gmail.com

ORCID: https://orcid.org/0000-0003-4597-7184

\section{Work of Museographer: Preparation of Museum Publication in Ukraine (end of the $19^{\text {th }}$ - first third of the $20^{\text {th }}$ century)}

Ukrainian museum editions of the end of the $19^{\text {th }}$ and the first third of the $20^{\text {th }}$ century are analyzed in the paper from the authors' work point of view - preparation of museographic texts. It is shown that cataloging, compiling of a guidebook, album, or inventory required preliminary processing of theoretical materials and attribution of objects. Quantitative indicators of items put into the printed forms of collections' presentations depended on the type of collection. Thus, numismatic and archaeological materials are usually more voluminous than inventories of other thematic groups (maps, old prints, fabrics, memorial collections).

But, the amount of the museographer's work did not depend on the goal and eventfulness of the publication since the catalogs of temporary exhibitions were no less quantitative than catalogs or inventories of collections of a certain profile. Studying of museum reports shows a wide horizon of the museographer's work on this specific format of publication. The authors of the reports accumulated and summarized various vectors of the museum's activity over a certain period.

Analysis of museum collections demonstrates the work of editorial commissions to outline the concept of the edition and its prospects. The materials of the collections concerned not only the problems of the museum sphere but also the issues of historical science and culture. Work on the issue required the concerted efforts of all authors.

Keywords: museography, museum edition, catalog, album, guide, report, collection, author, museographer 